\title{
The migration law of magnesium ions during freezing and melting processes
}

\author{
Zhang Yan $^{1}{ }^{1}$ $\cdot$ Liu Tongshuai ${ }^{1} \cdot$ Tang Yuanqing $^{1} \cdot$ Zhao Wanli $^{1} \cdot$ Ren Fangyun $^{1} \cdot$ Zhao Tongguo $^{1} \cdot$ Liu Yucan $^{1}$
}

Received: 11 June 2021 / Accepted: 23 November 2021 / Published online: 2 December 2021

(c) The Author(s) 2021

\begin{abstract}
To explore the migration law of magnesium ions $\left(\mathrm{Mg}^{2+}\right)$ during freezing and melting processes, laboratory simulation experiments involving freezing and melting were carried out to investigate the influence of ice thickness, freezing temperature, initial concentration, and initial $\mathrm{pH}$ on the distribution of $\mathrm{Mg}^{2+}$ in the ice-water system. The distribution coefficient " $\mathrm{K}$ " (the ratio of the $\mathrm{Mg}^{2+}$ concentration in the ice layer to the $\mathrm{Mg}^{2+}$ concentration in the water layer under ice) was used to characterize the migration ability of $\mathrm{Mg}^{2+}$. The results showed that during the freezing process, the concentration distribution of $\mathrm{Mg}^{2+}$ in the ice and water two-phase system was as follows: ice layer < water before freezing < water layer under ice; in other words, it migrated from ice layer to the water layer under ice. "K" decreased with increasing ice thickness, freezing temperature, initial concentration, and initial $\mathrm{pH}$; the higher the ice thickness, freezing temperature, initial concentration, and initial $\mathrm{pH}$ were, the higher the migration efficiency of $\mathrm{Mg}^{2+}$ into the water layer under ice was. During the melting process, $\mathrm{Mg}^{2+}$ was released in large amounts (50-60\%) at the initial stage (0-25\%) and in small amounts (25-100\%) uniformly in the middle and later periods. According to the change of $\mathrm{Mg}^{2+}$ concentration in ice melt water, an exponential model was established to predict $\mathrm{Mg}^{2+}$ concentration in ice melt period. The migration law of $\mathrm{Mg}^{2+}$ during the freezing and melting process was explained by using first principles.
\end{abstract}

Keywords Freezing and melting $\cdot \mathrm{Mg}^{2+}$; Migration law $\cdot$ Distribution coefficient "K" · First principles · Exponential decay

\section{Introduction}

Icebound is an important hydrological feature of surface water at high latitudes. More than 50 million lakes regularly freeze every year in the world, and the annual icebound time is more than 150 days (Verpoorter et al. 2014). During the icebound period, the penetration rate of light in water is weakened (Catalan 1992; Welch et al. 1987), which affects the photosynthesis of aquatic plants under the ice (Jewson et al. 2009). In addition, due to the ice sheet, the oxygen exchange process between the water layer under ice and

Responsible Editor: Philippe Garrigues

Zhang Yan

zhangyanytu@ytu.edu.cn

1 College of Civil Engineering, Yantai University, Yantai 264000, China the atmosphere is hindered, and the metabolism of aquatic organisms is affected; as a result, the self-purification capacity of the water layer is greatly reduced (Kirillin et al. 2012). Therefore, the environment of the water layer under ice cover has its own particularity.

Among the published literature on fresh water, only $2 \%$ involves the freezing process of water bodies (Hampton et al. 2015), and these studies mainly focus on heavy metals and nutrients. Pieters and Lawrence (2009) found in winter that in the Tailings Lake in northwest Canada, when the ice thickness reached $60-80 \mathrm{~cm}$, approximately $99 \%$ of the salt in the ice was discharged into the water layer under ice. Liu et al. $(2017,2019)$ found that during the growth period of sea ice in Lake Ulansuhai, due to the difference in equilibrium gradient, $\mathrm{Hg}, \mathrm{Zn}$, and $\mathrm{Pb}$ concentrations in water first increased during the freezing process; then the dynamic balance of ions between water and sediments was disturbed; and a portion of the $\mathrm{Hg}, \mathrm{Zn}$, and $\mathrm{Pb}$ concentrations migrated to sediments. Melak et al. (2016) found that in the Rift Valley 
Lake in Ethiopia in winter, $\mathrm{Cr}$ (VI) content ranged from 0.104 to $0.121 \mathrm{mg} \cdot \mathrm{L}^{-1}$, which exceeded the drinking water standard of Ethiopia and WHO by $0.05 \mathrm{mg} \cdot \mathrm{L}^{-1}$. Hampton et al. (2015) conducted the first global quantitative synthesis of 101 lakes and found that the total dissolved nitrogen and total nitrogen were higher in the water layer during the icebound period. Li et al. (2014) found that nutrient salts and algae continuously migrated to the water layer under ice in Lake Ulansuhai during the icebound period, leading to intensified eutrophication of the water layer under ice. Shafique et al. (2016) found that in the process of directional freezing of water layer, gas will also migrate downward with the growth of ice front. In addition, during the freezing process, some pollutants in the water were captured in the ice sheet, and in the spring, when it melted, the pollutants were released into the water environment within a short time, bringing great impacts to the aquatic ecosystem in early spring (Chiou et al. 1986; Huang et al. 2009, 2012).

Although there have been relevant studies on the migration law of heavy metals and organic matter in the process of icing, there are relatively few studies on the migration law and mechanism of inorganic ions in the process of ice sealing. As we all know, the lake water contains a variety of inorganic salts, such as $\mathrm{Li}^{+}, \mathrm{K}^{+}, \mathrm{Mg}^{2+} / \mathrm{Cl}^{-}$, and $\mathrm{SO}_{4}{ }^{2-}$ (Sun et al.1995). Magnesium is one of the major elements in lake water, and the content of $\mathrm{Mg}^{2+}$ in salt lakes is more abundant. The Dead Sea has the highest $\mathrm{Mg}^{2+}$ content, up to $190 \mathrm{~g} \cdot \mathrm{L}^{-1}$, with a total reserve of $230 \times 108 \mathrm{t}$ (Wisniak 2002), followed by the Great Salt Lake in the USA, with a content of $6 \times 108 \mathrm{t}$. During the ice sealing period, $\mathrm{Mg}^{2+}$ are discharged from the ice layer and then enter the water layer under ice, resulting in the concentration of $\mathrm{Mg}^{2+}$ in the water layer under ice. With the progress of icing process, the concentration of $\mathrm{Mg}^{2+}$ in the water layer under ice increases gradually (Cui et al. 2013). The continuous increase of $\mathrm{Mg}^{2+}$ concentration will affect the $\mathrm{pH}$ of sediments and endanger the ecological health of lakes (Chen et al. 2008; Dai 2016). In the process of ice melting, if the early concentrated release of $\mathrm{Mg}^{2+}$ in ice layer will also increase the concentration of $\mathrm{Mg}^{2+}$ in the water layer under ice. If it is used as source water, the treatment effect of the original treatment process is poor compared with that before freezing, which is easy to cause the increase of $\mathrm{Mg}^{2+}$ concentration in drinking water. The high concentration of $\mathrm{Mg}^{2+}$ in drinking water will affect the absorption of calcium ions. When the concentration of $\mathrm{Mg}^{2+}$ in the blood is higher than $1.0 \mathrm{mg} \cdot \mathrm{L}^{-1}$, it will lead to chronic hypermagnesemia (Musso 2009), and continuous hypermagnesemia will lead to chronic kidney disease (Guan 2017).

Therefore, this study took $\mathrm{Mg}^{2+}$ as the research object to carry out simulation experiments, which purpose was to explore the distribution law of $\mathrm{Mg}^{2+}$ in the ice water system during the freezing and melting process and investigate the influence of ice thickness, freezing temperature, initial concentration, and initial $\mathrm{pH}$ on the distribution of $\mathrm{Mg}^{2+}$ in the ice water phase. The distribution coefficient " $K$ " was used to characterize the $\mathrm{Mg}^{2+}$ migration ability. In addition, we discussed the release law of $\mathrm{Mg}^{2+}$ during the melting process. The above laws were explained from first principles. We hope that this study can draw researchers' attention to the changes in water quality under ice during the icebound period.

\section{Experimental section}

\section{Experimental setup}

In order to simulate the top-down directional freezing process of natural water, an open unidirectional freezing simulation device (Fig. 1) was designed to realize the vertical slow freezing of solution. The upper part of the device had an opening for one-way transfer of cold energy and a builtin reactor (wall thickness $5 \mathrm{~mm}$, outer diameter $20 \mathrm{~cm}$, height $37.5 \mathrm{~cm}$ ) with high borosilicate glass. Around and at the bottom of the glass were wrapped with EPS (expanded polystyrene) insulation material to block the heat transfer between the reactor and outside. To facilitate icicle removal, a temperature-controlled heating sheet was wrapped between the outer wall of the reactor and insulation material, and a resistance wire (nickel-chromium alloy) thickness measuring device was placed in the barrel; the resistance wire displacement difference indicates the ice thickness. The above devices were placed in a chest freezer (BC/BD-519 HEX, Haier, Qingdao, China) with a volume of $519 \mathrm{~L}$ and a minimum refrigeration temperature of $-40^{\circ} \mathrm{C}$.

The ice melt device was a self-made stainless steel funnel (Fig. 1). The ice layer was stored in the upper part, the beaker was placed in the lower part, and the electronic balance was placed under the beaker to weigh the ice melt-water.

\section{Experimental design and methods}

To explore the migration law of $\mathrm{Mg}^{2+}$ in the water freezing process, as well as the influence of ice thickness, freezing temperature, initial concentration, and initial $\mathrm{pH}$ on the migration law, the experimental design was as follows:

(1) To study the effect of ice thickness on the migration law of $\mathrm{Mg}^{2+}$ in the freezing process, a standard solution of $\mathrm{Mg}^{2+}$ with a concentration of $500 \mathrm{mg} \cdot \mathrm{L}^{-1}$ was pre- 

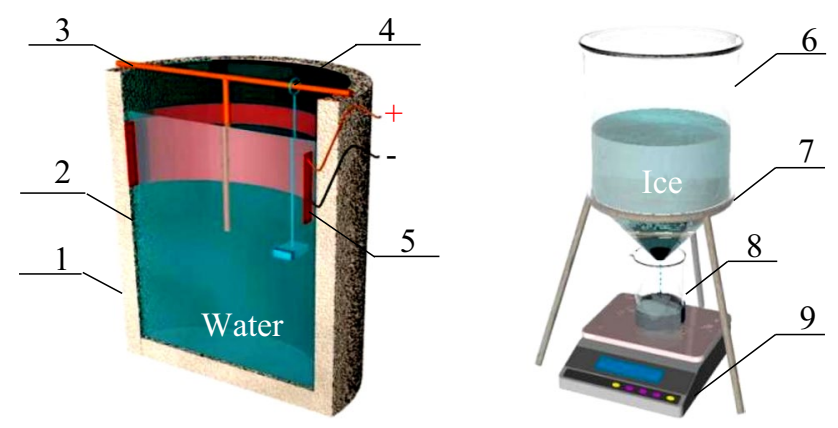

Fig. 1 Schematic diagram of freeze-melt experimental device: on the left is the freezing device; on the right is the ice melt device (1 EPS insulation; 2 glass cylindrical barrel; 3 T-shaped bracket; 4 measuring ice thickness device; 5 heating sheet; 6 ice melting funnel; 7 funnel support; 8 beaker; 9 electronic balance)

pared and placed in five freezing simulators. Then, an 8-L water sample with $\mathrm{pH} 7$ was put into each simulator, the height of water was $28 \mathrm{~cm}$, and devices were placed in a low-temperature box at $-15{ }^{\circ} \mathrm{C}$. When the ice thickness reached $4 \mathrm{~cm}, 8 \mathrm{~cm}, 12 \mathrm{~cm}, 16 \mathrm{~cm}$, and $20 \mathrm{~cm}$; the reactors were removed.

(2) To study the effects of freezing temperature on the migration law of $\mathrm{Mg}^{2+}$ in the freezing process, a standard solution of $\mathrm{Mg}^{2+}$ with a concentration of $500 \mathrm{mg} \cdot \mathrm{L}^{-1}$ was prepared and placed in five freezing simulators. Then, an 8 -L water sample with $\mathrm{pH} 7$ was put into each simulator, the height of water was $28 \mathrm{~cm}$, and devices were placed in a low temperature box at $-5{ }^{\circ} \mathrm{C},-10{ }^{\circ} \mathrm{C},-15{ }^{\circ} \mathrm{C},-20$ ${ }^{\circ} \mathrm{C}$, and $-25^{\circ} \mathrm{C}$. When the ice thickness reached $12 \mathrm{~cm}$, the reactors were removed.

(3) To study the effects of initial concentration on the migration law of $\mathrm{Mg}^{2+}$ in the freezing process, referring to Guidelines for Drinking-water Quality set by the WHO (2011), the maximum allowable level of total hardness (calculated by $\mathrm{CaCO}_{3}$ ) of drinking water shall not exceed $500 \mathrm{mg} \cdot \mathrm{L}^{-1}$. The standard solutions of $\mathrm{Mg}^{2+}$ with concentrations of $300 \mathrm{mg} \cdot \mathrm{L}^{-1}, 400 \mathrm{mg} \cdot \mathrm{L}^{-1}, 500 \mathrm{mg} \cdot \mathrm{L}^{-1}$, $600 \mathrm{mg} \cdot \mathrm{L}^{-1}$, and $700 \mathrm{mg} \cdot \mathrm{L}^{-1}$ were placed in five freezing simulators. Then, an 8-L water sample with $\mathrm{pH} 7$ was placed into each simulator, the height of water was $28 \mathrm{~cm}$, and devices were placed in a low-temperature box at -15 ${ }^{\circ} \mathrm{C}$. When the ice thickness reached $12 \mathrm{~cm}$; the reactors were removed.

(4) To study the effects of initial $\mathrm{pH}$ on the migration law of $\mathrm{Mg}^{2+}$ in the freezing process, a standard solution of $\mathrm{Mg}^{2+}$ with a concentration of $500 \mathrm{mg} \cdot \mathrm{L}^{-1}$ was prepared and placed in five freezing simulators. Then, an 8-L water sample was put into each simulator; the height of water was $28 \mathrm{~cm}$; and the $\mathrm{pH}$ of the water samples were adjusted to 5.5, 6.5, 7.5, 8.5, and 9.5 by dropping $\mathrm{HCl}$ and $\mathrm{NaOH}$ solution and placing devices in a low temperature box at $-15{ }^{\circ} \mathrm{C}$. When the ice thickness reached $12 \mathrm{~cm}$, the reactors were removed.

The ice sample obtained from the above freezing experiment was put into a beaker, melted in a constant temperature box $\left(25^{\circ} \mathrm{C}\right)$, and the water under the ice was evenly mixed and put into a beaker for detecting.

The process of ice samples acquisition in the melting experiment was the same as that in the simulated freezing experiment. The ice samples with different ice thickness, freezing temperature, initial concentration, and initial $\mathrm{pH}$ are weighed, placed in the ice-melt device, and melted in the incubator $\left(25^{\circ} \mathrm{C}\right)$. Take the ice melt water four times on average according to the ice sample weight, and the weight of each melt water accounts for $25 \%$ of the total weight of the ice sample. The melt water weight reaches $25 \%$ of the total weight of ice sample for the first time as melting 1, $25 \%$ of the total weight of ice sample for the second time as melting 2, 25\% of the total weight of ice sample for the third time as melting 3 , and $25 \%$ of the total weight of ice sample for the fourth time as melting 4 . The concentrations of $\mathrm{Mg}^{2+}$ were detected respectively.

\section{Sample detection methods}

The $\mathrm{Mg}^{2+}$ concentrations in ice melt water and the water layer under ice were measured in accordance with the Water and Wastewater Monitoring Analysis Method (4th ed.) (2002), and the standard deviation of the detection results was controlled within 5\%. The generated solid was observed by optical microscope with an XST-107 T Digital Microscope, which can achieve a magnification of up to 1000 times.

\section{Data analysis methods}

The distribution coefficient " $\mathrm{K}$ " is defined as the ratio between the average concentration of $\mathrm{Mg}^{2+}$ in the ice layer and the average concentration of $\mathrm{Mg}^{2+}$ in the water layer under ice, which reflects the migration ability and discharge effect of $\mathrm{Mg}^{2+}$ in the process of water freezing:

$K=\frac{C_{i}}{C_{w}}$

where $C_{i}$ is the average concentration of $\mathrm{Mg}^{2+}$ in the ice layer and $C_{w}$ is the average concentration of $\mathrm{Mg}^{2+}$ in the water layer under ice $\left(\mathrm{mg} \cdot \mathrm{L}^{-1}\right)$. 


\section{Results}

\section{Migration law of $\mathrm{Mg}^{2+}$ during the freezing process}

\section{Migration of $\mathrm{Mg}^{2+}$ in the ice and water two-phase system under different ice thicknesses conditions}

The ice melt water and water layer under ice obtained from different ice thickness conditions were collected, and the concentrations of $\mathrm{Mg}^{2+}$ were measured (Table 1). The distributions of $\mathrm{Mg}^{2+}$ in the ice and water two-phase under different ice thickness conditions are shown in Fig. 2:

As shown in Fig. 2, when the ice thicknesses were $4 \mathrm{~cm}$, $8 \mathrm{~cm}, 12 \mathrm{~cm}, 16 \mathrm{~cm}$, and $20 \mathrm{~cm}$, the concentrations of $\mathrm{Mg}^{2+}$ in ice layer were significantly lower than that of raw water by $500 \mathrm{mg} \cdot \mathrm{L}^{-1}$, while the concentrations of $\mathrm{Mg}^{2+}$ in the water layer under ice were significantly higher than that of raw water by $500 \mathrm{mg} \cdot \mathrm{L}^{-1}$. The concentrations of $\mathrm{Mg}^{2+}$ in ice layer were $0.091,0.085,0.094,0.107$, and 0.133 times of the initial concentration respectively, and the concentrations of $\mathrm{Mg}^{2+}$ in the water layer under ice were $1.146,1.363,1.678$, 2.151, and 2.936 times of the initial concentration respectively. The results showed that the higher the ice thickness, the higher the concentration of $\mathrm{Mg}^{2+}$ in the ice layer, and the higher the concentration of $\mathrm{Mg}^{2+}$ in the water layer under ice. With increased ice thickness, the distribution coefficient "K" decreased. In other words, with increased ice thickness, the ability of $\mathrm{Mg}^{2+}$ to migrate into the water layer under ice became stronger.

\section{Migration of $\mathrm{Mg}^{2+}$ in the ice and water two-phase system under different freezing temperature conditions}

The ice melt-water and the water layer under ice obtained from different freezing temperature conditions were collected, and the concentrations of $\mathrm{Mg}^{2+}$ were measured (Table 2). The distributions of $\mathrm{Mg}^{2+}$ in the ice and water two-phase system under different freezing temperature conditions are shown in Fig. 3.

As shown in Fig. 3, when the freezing temperatures were $-5{ }^{\circ} \mathrm{C},-10{ }^{\circ} \mathrm{C},-15{ }^{\circ} \mathrm{C},-20{ }^{\circ} \mathrm{C}$, and $-25{ }^{\circ} \mathrm{C}$, the

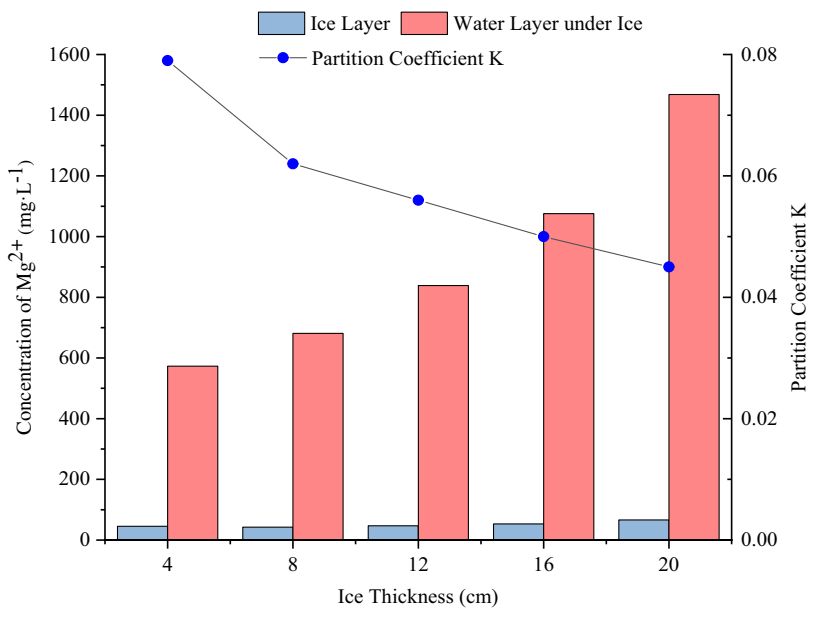

Fig. 2 Distributions of $\mathrm{Mg}^{2+}$ in the ice and water two-phase system with different ice thicknesses

concentrations of $\mathrm{Mg}^{2+}$ in ice layer were significantly lower than that of raw water by $500 \mathrm{mg} \cdot \mathrm{L}^{-1}$, while the concentrations of $\mathrm{Mg}^{2+}$ in the water layer under ice were significantly higher than that of raw water by $500 \mathrm{mg} \cdot \mathrm{L}^{-1}$. The concentrations of $\mathrm{Mg}^{2+}$ in ice layer were $0.052,0.076,0.094,0.108$, and 0.125 times of the initial concentration respectively, and the concentrations of $\mathrm{Mg}^{2+}$ in the water layer under ice were $1.73,1.70,1.68,1.63$, and 1.60 times of the initial concentration respectively. Hence, the observation was the lower the freezing temperature, the higher the concentration of $\mathrm{Mg}^{2+}$ in the ice layer, and the lower the concentration of $\mathrm{Mg}^{2+}$ in the water layer under ice. With decreased freezing temperature, the distribution coefficient " $K$ " increased. In other words, with decreased freezing temperature, the ability of $\mathrm{Mg}^{2+}$ to migrate into the water layer under ice became weaker.

\section{Migration of $\mathrm{Mg}^{2+}$ in the ice and water two-phase system under different initial concentration conditions}

The ice melt water and water layer under ice obtained from different initial concentration conditions were collected, and
Table 1 Concentrations of $\mathrm{Mg}^{2+}$ in ice and water system from different icing thicknesses

\begin{tabular}{|c|c|c|c|c|c|c|}
\hline $\begin{array}{l}\text { Ice } \\
\text { thickness } \\
(\mathrm{cm})\end{array}$ & $\begin{array}{l}\text { Freezing } \\
\text { temperature } \\
\left({ }^{\circ} \mathrm{C}\right)\end{array}$ & $\begin{array}{l}\text { Initial } \\
\text { concentration }\left(\mathrm{mg} \cdot \mathrm{L}^{-1}\right)\end{array}$ & $\mathrm{pH}$ & $\begin{array}{l}\text { Concentration } \\
\text { in ice layer } \\
\left(\mathrm{mg} \cdot \mathrm{L}^{-1}\right)\end{array}$ & $\begin{array}{l}\text { Concentration of } \\
\text { water layer under ice } \\
\left(\mathrm{mg} \cdot \mathrm{L}^{-1}\right)\end{array}$ & $\mathrm{K}$ \\
\hline 4 & -15 & 500 & 7 & 45.458 & 573.08 & 0.079 \\
\hline 8 & -15 & 500 & 7 & 42.461 & 681.276 & 0.062 \\
\hline 12 & -15 & 500 & 7 & 46.953 & 838.829 & 0.056 \\
\hline 16 & -15 & 500 & 7 & 53.276 & 1075.645 & 0.050 \\
\hline 20 & -15 & 500 & 7 & 66.477 & 1468.248 & 0.045 \\
\hline
\end{tabular}


Table 2 Concentrations of $\mathrm{Mg}^{2+}$ in ice and water system from different freezing temperatures

\begin{tabular}{|c|c|c|c|c|c|c|}
\hline $\begin{array}{l}\text { Freezing } \\
\text { temperature } \\
\left({ }^{\circ} \mathrm{C}\right)\end{array}$ & $\begin{array}{l}\text { Ice } \\
\text { thickness } \\
(\mathrm{cm})\end{array}$ & $\begin{array}{l}\text { Initial } \\
\text { concentration }\left(\mathrm{mg} \cdot \mathrm{L}^{-1}\right)\end{array}$ & $\mathrm{pH}$ & $\begin{array}{l}\text { Concentration } \\
\text { in ice layer } \\
\left(\mathrm{mg} \cdot \mathrm{L}^{-1}\right)\end{array}$ & $\begin{array}{l}\text { Concentration of } \\
\text { water layer under ice } \\
\left(\mathrm{mg} \cdot \mathrm{L}^{-1}\right)\end{array}$ & $\mathrm{K}$ \\
\hline-5 & 12 & 500 & 7 & 26.077 & 862.516 & 0.030 \\
\hline-10 & 12 & 500 & 7 & 37.771 & 849.896 & 0.044 \\
\hline-15 & 12 & 500 & 7 & 46.978 & 838.829 & 0.056 \\
\hline-20 & 12 & 500 & 7 & 53.919 & 815.148 & 0.066 \\
\hline-25 & 12 & 500 & 7 & 62.261 & 798.827 & 0.078 \\
\hline
\end{tabular}

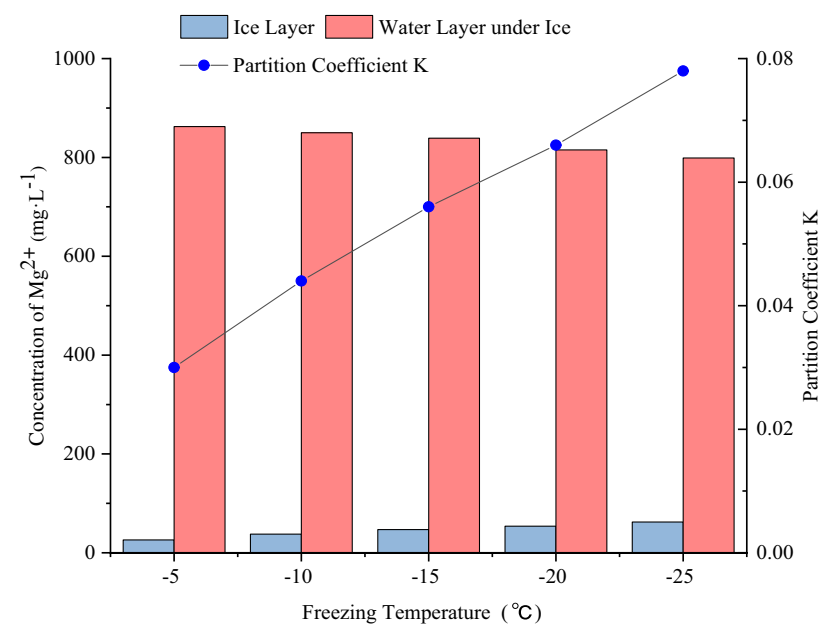

Fig. 3 Distributions of $\mathrm{Mg}^{2+}$ in the ice and water two-phase system with different freezing temperatures

the concentrations of $\mathrm{Mg}^{2+}$ were measured (Table 3). The distributions of $\mathrm{Mg}^{2+}$ in the ice and water two-phase system under different initial concentration conditions are shown in Fig. 4.

As shown in Fig. 4, when the concentrations of $\mathrm{Mg}^{2+}$ standard solution were $300 \mathrm{mg} \cdot \mathrm{L}^{-1}, 400 \mathrm{mg} \cdot \mathrm{L}^{-1}$, $500 \mathrm{mg} \cdot \mathrm{L}^{-1}, 600 \mathrm{mg} \cdot \mathrm{L}^{-1}$, and $700 \mathrm{mg} \cdot \mathrm{L}^{-1}$, the concentrations of $\mathrm{Mg}^{2+}$ in ice layer were significantly lower than that of raw water, while the concentrations of $\mathrm{Mg}^{2+}$ in the water layer under ice were significantly higher than that of raw water. The concentrations of $\mathrm{Mg}^{2+}$ in ice layer were $0.054,0.072,0.094,0.107$, and 0.128 times of the initial concentrations respectively, and the concentrations of $\mathrm{Mg}^{2+}$ in the water layer under ice were 1.480, 1.509, 1.678, 1.701, and 1.787 times of the initial concentration respectively. The results showed that the higher the initial concentration, the higher the concentration of $\mathrm{Mg}^{2+}$ in the ice layer, and the higher the concentration of $\mathrm{Mg}^{2+}$ in the water layer under ice. With increased initial concentration, the distribution coefficient " $K$ " decreased. In other words, with increased initial concentration, the ability of $\mathrm{Mg}^{2+}$ to migrate into the water layer under ice became stronger.

\section{Migration of $\mathrm{Mg}^{2+}$ in the ice and water two-phase system under different initial $\mathrm{pH}$ conditions}

The ice melt water and water layer under ice obtained from different initial $\mathrm{pH}$ conditions were collected, and the concentrations of $\mathrm{Mg}^{2+}$ were measured (Table 4). The distributions of $\mathrm{Mg}^{2+}$ in the ice and water two-phase system under different initial pH conditions are shown in Fig. 5.

As shown in Fig. 5, when the $\mathrm{pH}$ of magnesium standard solution were 5.5, 6.5, 7.5, 8.5, and 9.5, the concentrations of $\mathrm{Mg}^{2+}$ in ice layer were significantly lower than that of raw water by $500 \mathrm{mg} \cdot \mathrm{L}^{-1}$, while the concentrations of $\mathrm{Mg}^{2+}$ in the water layer under ice were significantly higher than that of raw water by $500 \mathrm{mg} \cdot \mathrm{L}^{-1}$. The concentrations of $\mathrm{Mg}^{2+}$ in ice layer were $0.103,0.094,0.088,0.082$, and 0.075 times of the initial concentration, respectively, and the concentrations of $\mathrm{Mg}^{2+}$ in the water layer under ice were 1.640, 1.678, $1.699,1.717$, and 1.730 times of the initial concentration respectively. The results showed that the higher the initial $\mathrm{pH}$, the lower the concentration of $\mathrm{Mg}^{2+}$ in the ice layer,
Table 3 Concentrations of $\mathrm{Mg}^{2+}$ in ice and water system from different initial concentrations

\begin{tabular}{lllllll}
\hline $\begin{array}{l}\text { Initial concen- } \\
\text { tration }\left(\mathrm{mg} \cdot \mathrm{L}^{-1}\right)\end{array}$ & $\begin{array}{l}\text { Ice thick- } \\
\text { ness }(\mathrm{cm})\end{array}$ & $\begin{array}{l}\text { Freezing } \\
\text { temperature } \\
\left({ }^{\circ} \mathrm{C}\right)\end{array}$ & $\mathrm{pH}$ & $\begin{array}{l}\text { Concentration in } \\
\text { ice layer }\left(\mathrm{mg} \cdot \mathrm{L}^{-1}\right)\end{array}$ & $\begin{array}{l}\text { Concentration of water } \\
\text { layer under ice }\left(\mathrm{mg} \cdot \mathrm{L}^{-1}\right)\end{array}$ & $\mathrm{K}$ \\
\hline 300 & 12 & -15 & 7 & 26.876 & 443.851 & 0.061 \\
400 & 12 & -15 & 7 & 35.750 & 603.574 & 0.059 \\
500 & 12 & -15 & 7 & 46.978 & 838.829 & 0.056 \\
600 & 12 & -15 & 7 & 53.455 & 1020.465 & 0.052 \\
700 & 12 & -15 & 7 & 63.879 & 1250.852 & 0.051 \\
\hline
\end{tabular}




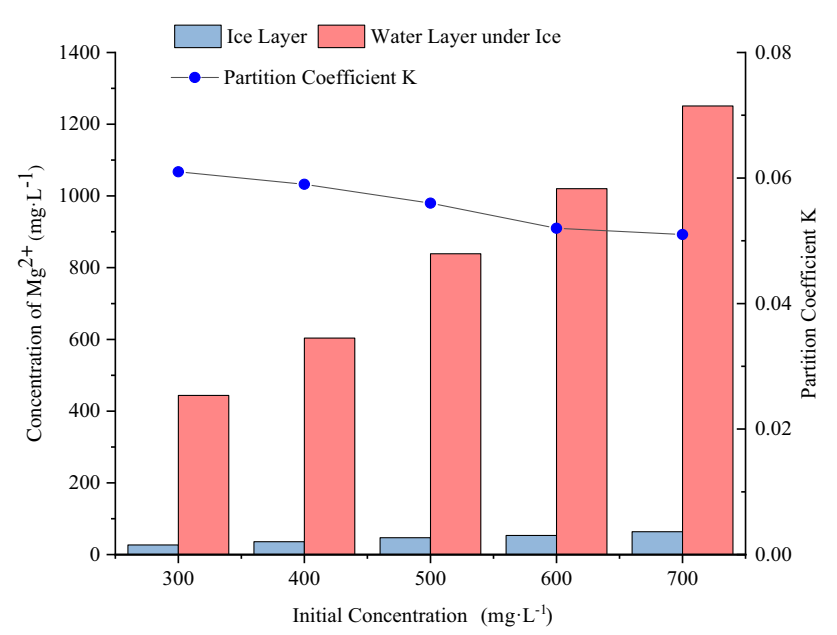

Fig. 4 Distributions of $\mathrm{Mg}^{2+}$ in the ice and water two-phase system with different initial concentrations

and the higher the concentration of $\mathrm{Mg}^{2+}$ in the water layer under ice. With increased initial $\mathrm{pH}$, the distribution coefficient " $\mathrm{K}$ " decreased. In other words, with increased initial $\mathrm{pH}$, the ability of $\mathrm{Mg}^{2+}$ to migrate into the water layer under ice became stronger.

\section{Release law of $\mathrm{Mg}^{2+}$ during ice melting}

\section{Release law of $\mathrm{Mg}^{2+}$ in the melting process of ice layers under different ice thicknesses}

As shown in Fig. 6a, for melting 1 of ice samples obtained from different ice thicknesses $(4 \mathrm{~cm}, 8 \mathrm{~cm}, 12 \mathrm{~cm}, 16 \mathrm{~cm}$, and $20 \mathrm{~cm}$ ), the concentrations of $\mathrm{Mg}^{2+}$ were $84.375 \mathrm{mg} \cdot \mathrm{L}^{-1}$, $89.634 \mathrm{mg} \cdot \mathrm{L}^{-1}, 97.745 \mathrm{mg} \cdot \mathrm{L}^{-1}, 118.856 \mathrm{mg} \cdot \mathrm{L}^{-1}$, and $155.48 \mathrm{mg} \cdot \mathrm{L}^{-1}$, respectively, which were $1.97-2.24$ times the average concentration of $\mathrm{Mg}^{2+}$ in the ice layer. The ratios of $\mathrm{Mg}^{2+}$ concentration in melting 1 to $\mathrm{Mg}^{2+}$ concentration in corresponding ice layer were $49.36 \%, 51.06 \%$, $52.64 \%, 53.34 \%$, and $56.07 \%$, respectively. For meltings 2-4 of ice samples obtained from different ice thicknesses, the average concentrations of $\mathrm{Mg}^{2+}$ were $28.854 \mathrm{mg} \cdot \mathrm{L}^{-1}$, $28.641 \mathrm{mg} \cdot \mathrm{L}^{-1}, 29.31 \mathrm{mg} \cdot \mathrm{L}^{-1}, 34.664 \mathrm{mg} \cdot \mathrm{L}^{-1}$, and
$40.601 \mathrm{mg} \cdot \mathrm{L}^{-1}$, respectively, which were $0.58-0.68$ times of the average concentration of $\mathrm{Mg}^{2+}$ in the ice layer. The ratios of the average $\mathrm{Mg}^{2+}$ concentration in meltings 2-4 to the $\mathrm{Mg}^{2+}$ concentration in the corresponding ice layer were $50.64 \%, 48.94 \%, 47.36 \%, 46.66 \%$, and $43.93 \%$, respectively.

\section{Release law of $\mathrm{Mg}^{2+}$ in the melting process of ice layers under different freezing temperatures}

As shown in Fig. 6b, for melting 1 of ice samples obtained from different freezing temperatures $\left(-5{ }^{\circ} \mathrm{C},-10\right.$ $\left.{ }^{\circ} \mathrm{C},-15{ }^{\circ} \mathrm{C},-20{ }^{\circ} \mathrm{C},-25{ }^{\circ} \mathrm{C}\right)$, the concentrations of $\mathrm{Mg}^{2+}$ were $50.851 \mathrm{mg} \cdot \mathrm{L}^{-1}, 79.125 \mathrm{mg} \cdot \mathrm{L}^{-1}, 97.745 \mathrm{mg} \cdot \mathrm{L}^{-1}$, $120.852 \mathrm{mg} \cdot \mathrm{L}^{-1}$, and $150.452 \mathrm{mg} \cdot \mathrm{L}^{-1}$, respectively, which were 1.98-2.26 times of the average concentration of $\mathrm{Mg}^{2+}$ in the ice layer. The ratios of $\mathrm{Mg}^{2+}$ concentration in melting 1 to $\mathrm{Mg}^{2+}$ concentration in corresponding ice layer were $50.29 \%, 49.53 \%, 52.93 \%, 53.45 \%$, and $56.60 \%$, respectively. For meltings $2-4$ of ice samples obtained from different freezing temperatures, the average concentrations of $\mathrm{Mg}^{2+}$ were $16.752 \mathrm{mg} \cdot \mathrm{L}^{-1}, 26.879 \mathrm{mg} \cdot \mathrm{L}^{-1}$, $28.98 \mathrm{mg} \cdot \mathrm{L}^{-1}, 35.114 \mathrm{mg} \cdot \mathrm{L}^{-1}$, and $38.452 \mathrm{mg} \cdot \mathrm{L}^{-1}$, respectively, which were $0.57-0.67$ times of the average

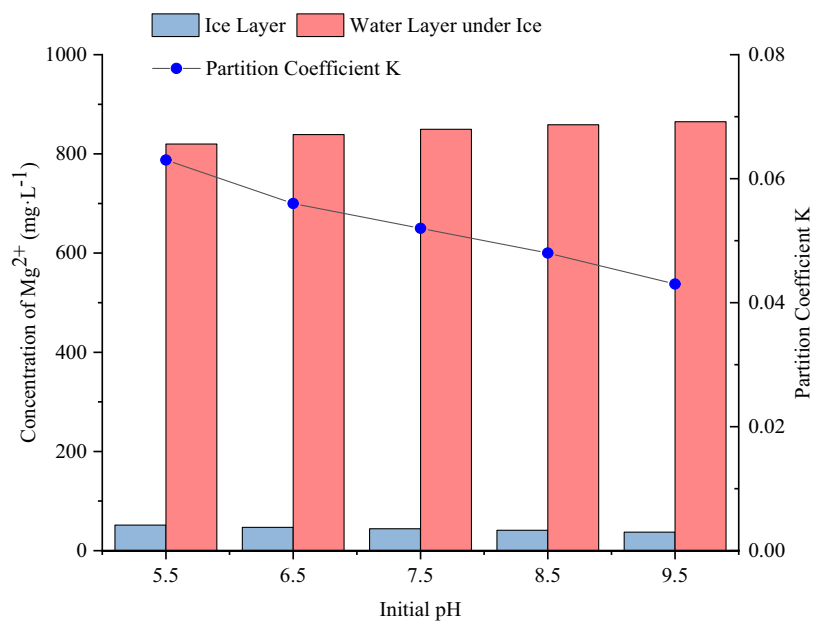

Fig. 5 Distributions of $\mathrm{Mg}^{2+}$ in the ice and water two-phase system with different initial $\mathrm{pH}$
Table 4 Concentrations of $\mathrm{Mg}^{2+}$ in ice and water system from different initial $\mathrm{pH}$

\begin{tabular}{lllllll}
\hline $\mathrm{pH}$ & $\begin{array}{l}\text { Ice thick- } \\
\text { ness }(\mathrm{cm})\end{array}$ & $\begin{array}{l}\text { Freezing } \\
\text { temperature } \\
\left({ }^{\circ} \mathrm{C}\right)\end{array}$ & $\begin{array}{l}\text { Initial concen- } \\
\text { tration }\left(\mathrm{mg} \cdot \mathrm{L}^{-1}\right)\end{array}$ & $\begin{array}{l}\text { Concentration in } \\
\text { ice layer }\left(\mathrm{mg} \cdot \mathrm{L}^{-1}\right)\end{array}$ & $\begin{array}{l}\text { Concentration of water } \\
\text { layer under ice }\left(\mathrm{mg} \cdot \mathrm{L}^{-1}\right)\end{array}$ & $\mathrm{K}$ \\
\hline 5.5 & 12 & -15 & 500 & 51.586 & 819.873 & 0.063 \\
6.5 & 12 & -15 & 500 & 46.953 & 838.829 & 0.056 \\
7.5 & 12 & -15 & 500 & 44.213 & 849.652 & 0.052 \\
8.5 & 12 & -15 & 500 & 41.210 & 858.745 & 0.048 \\
9.5 & 12 & -15 & 500 & 37.368 & 864.785 & 0.043 \\
\hline
\end{tabular}



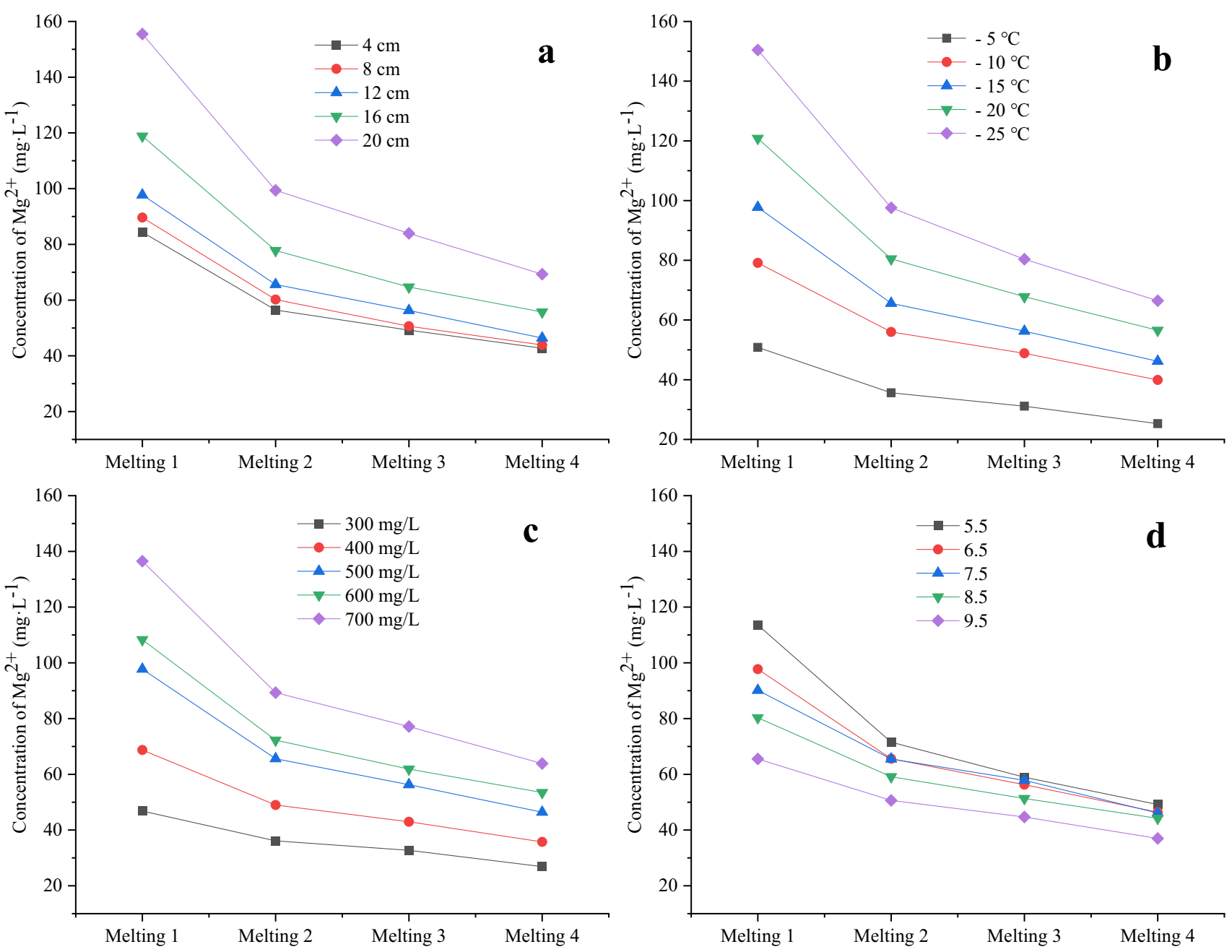

Fig. 6 Release law of $\mathrm{Mg}^{2+}$ during the ice melting process under different freezing conditions. a Ice thickness, $\mathbf{b}$ freezing temperature, $\mathbf{c}$ initial concentration, $\mathbf{d}$ initial $\mathrm{pH}$

concentration of $\mathrm{Mg}^{2+}$ in the ice layer. The ratios of the average $\mathrm{Mg}^{2+}$ concentration in meltings 2-4 to the $\mathrm{Mg}^{2+}$ concentration in the corresponding ice layer were $49.71 \%$, $50.47 \%, 47.07 \%, 46.55 \%$, and $43.4 \%$, respectively.

\section{Release law of $\mathrm{Mg}^{2+}$ in the melting process of ice layers under different initial concentrations}

As shown in Fig. 6c, for melting 1 of ice samples obtained from different initial concentrations $\left(300 \mathrm{mg} \cdot \mathrm{L}^{-1}\right.$, $\left.400 \mathrm{mg} \cdot \mathrm{L}^{-1}, 500 \mathrm{mg} \cdot \mathrm{L}^{-1}, 600 \mathrm{mg} \cdot \mathrm{L}^{-1}, 700 \mathrm{mg} \cdot \mathrm{L}^{-1}\right)$, the concentrations of $\mathrm{Mg}^{2+}$ were $46.838 \mathrm{mg} \cdot \mathrm{L}^{-1}, 68.734 \mathrm{mg} \cdot \mathrm{L}^{-1}$, $97.745 \mathrm{mg} \cdot \mathrm{L}^{-1}, 108.335 \mathrm{mg} \cdot \mathrm{L}^{-1}$, and $136.476 \mathrm{mg} \cdot \mathrm{L}^{-1}$, respectively, which were 1.74-2.14 times of the average concentration of $\mathrm{Mg}^{2+}$ in the ice layer. The ratios of $\mathrm{Mg}^{2+}$ concentration in melting 1 to $\mathrm{Mg}^{2+}$ concentration in corresponding ice layer were $43.57 \%, 48.06 \%, 52.64 \%, 50.67 \%$, and $53.41 \%$, respectively. For meltings $2-4$ of ice samples with different initial concentration, the average concentrations of $\mathrm{Mg}^{2+}$ were $20.222 \mathrm{mg} \cdot \mathrm{L}^{-1}, 24.772 \mathrm{mg} \cdot \mathrm{L}^{-1}, 29.310 \mathrm{mg} \cdot \mathrm{L}^{-1}$, $35.162 \mathrm{mg} \cdot \mathrm{L}^{-1}$, and $39.680 \mathrm{mg} \cdot \mathrm{L}^{-1}$, respectively, which were $0.62-0.75$ times of the average concentration of $\mathrm{Mg}^{2+}$ in the ice layer. The ratios of the average $\mathrm{Mg}^{2+}$ concentration in meltings 2-4 to the $\mathrm{Mg}^{2+}$ concentration in the corresponding ice layer were $56.43 \%, 51.94 \%, 47.36 \%, 49.33 \%$, and $46.59 \%$, respectively. 
Release law of $\mathrm{Mg}^{2+}$ in the melting process of ice layers under different initial $\mathrm{pH}$

As shown in Fig. 6d, for melting 1 of ice samples obtained from different initial $\mathrm{pH}(5.5,6.5,7.5,8.5,9.5)$, the concentrations of $\mathrm{Mg}^{2+}$ were $113.596 \mathrm{mg} \cdot \mathrm{L}^{-1}, 97.745 \mathrm{mg} \cdot \mathrm{L}^{-1}$, $90.125 \mathrm{mg} \cdot \mathrm{L}^{-1}, 80.29 \mathrm{mg} \cdot \mathrm{L}^{-1}$, and $65.523 \mathrm{mg} \cdot \mathrm{L}^{-1}$, respectively, which were $1.77-2.31$ times of the average concentration of $\mathrm{Mg}^{2+}$ in the ice layer. The ratios of $\mathrm{Mg}^{2+}$ concentration in melting 1 to $\mathrm{Mg}^{2+}$ concentration in corresponding ice layer were $59.01 \%, 54.69 \%, 52.64 \%, 48.79 \%$, and $44.59 \%$, respectively. For meltings $2-4$ of ice samples with different initial $\mathrm{pH}$, the average concentrations of $\mathrm{Mg}^{2+}$ were $27.696 \mathrm{mg} \cdot \mathrm{L}^{-1}, 29.310 \mathrm{mg} \cdot \mathrm{L}^{-1}, 31.422 \mathrm{mg} \cdot \mathrm{L}^{-1}$, $32.171 \mathrm{mg} \cdot \mathrm{L}^{-1}$, and $27.497 \mathrm{mg} \cdot \mathrm{L}^{-1}$, respectively, which were $0.55-0.74$ times of the average concentration of $\mathrm{Mg}^{2+}$ in the ice layer. The ratios of the average $\mathrm{Mg}^{2+}$ concentration in meltings $2-4$ to the $\mathrm{Mg}^{2+}$ concentration in the corresponding ice layer were $40.99 \%, 45.31 \%, 47.36 \%, 51.21 \%$, and $55.41 \%$, respectively.

\section{Analysis and discussion}

\section{Migration mechanism of $\mathrm{Mg}^{2+}$ during the freezing process}

According to Guidelines for Drinking-water Quality set by the WHO (2011), the maximum allowable level of total hardness (calculated by detecting $\mathrm{CaCO}_{3}$ ) of drinking water shall not exceed $500 \mathrm{mg} \cdot \mathrm{L}^{-1}$. In the simulated freezing experiment, the detection range of $\mathrm{Mg}^{2+}$ in ice layers was 26.077-66.477 $\mathrm{mg} \cdot \mathrm{L}^{-1}$ when the concentration of $\mathrm{Mg}^{2+}$ was $500 \mathrm{mg} \cdot \mathrm{L}^{-1}$, which is lower than the limit value of hardness in the Guidelines for Drinking-water Quality, while the detection range of $\mathrm{Mg}^{2+}$ in the water layers under ice was $573.08-1468.248 \mathrm{mg} \cdot \mathrm{L}^{-1}$, which is significantly higher than the initial concentration of $500 \mathrm{mg} \cdot \mathrm{L}^{-1}$ and far beyond the limit value of hardness in the Guidelines for Drinkingwater Quality. Under different conditions, the concentration relationship of $\mathrm{Mg}^{2+}$ in the ice and water two-phase system is as follows: ice layer $<$ water layer before freezing $<$ water layer under ice; in other words, $\mathrm{Mg}^{2+}$ migrate from the ice layer to the water layer under ice during the freezing process. The migration process can be explained by first principles.

From the microscopic point of view, in the unfrozen state, water molecules are relatively free, and $\mathrm{Mg}^{2+}$ in water are tightly surrounded by water molecules(Wang et al. 2010). When the temperature decreases, energy decreases; water molecules and $\mathrm{Mg}^{2+}$ begin to move. At a certain time, the position structure of water molecules and $\mathrm{Mg}^{2+}$ appears to be optimal (Fig. 7), and the energy is optimal for the coexistence of water molecules and $\mathrm{Mg}^{2+}$. As the energy continues to decrease, water molecules begin to transform into tiny ice crystals. At this time, water molecules not only interact with $\mathrm{Mg}^{2+}$ but also form ice crystal structures, which result in insufficient free water molecules surrounding $\mathrm{Mg}^{2+}$. From the microscopic model, $\mathrm{Mg}^{2+}$ are more stable in the water phase than in the ice phase. Due to the tendency of ions to move towards the stable phase, $\mathrm{Mg}^{2+}$ will migrate from the unstable ice phase to the stable water phase in the ice and water two-phase system.

From a macroscopic point of view, when water begins to freeze, the free water molecules are transformed into regular ice structures, and the ice and water two-phase system appears in the solution. The energy that must be overcome by $\mathrm{Mg}^{2+}$ in combination with the ice phase is small (Sun et al. 2018), so the energy released by $\mathrm{Mg}^{2+}$ in combination with the ice phase is small, and the energy of the whole system is high, so the system formed in the ice layer is unstable. The energy to be overcome by $\mathrm{Mg}^{2+}$ in combination with the water phase is large, so the energy released by $\mathrm{Mg}^{2+}$ in combination with the water phase is large, and the energy of the whole system is low, so the system formed in the water layer is relatively stable. Therefore, $\mathrm{Mg}^{2+}$ migrates from the ice layer to the water layer under ice.

\section{Effects of different factors on $\mathbf{M g}^{2+}$ migration during the freezing process}

In the simulated freezing experiment, the distribution coefficient " $K$ " was negatively correlated with ice thickness, freezing temperature, initial concentration, and initial $\mathrm{pH}$; in other words, the larger the ice thickness, freezing
Fig. 7 Schematic diagram of $\mathrm{Mg}^{2+}$ migration in the ice and water two-phase system

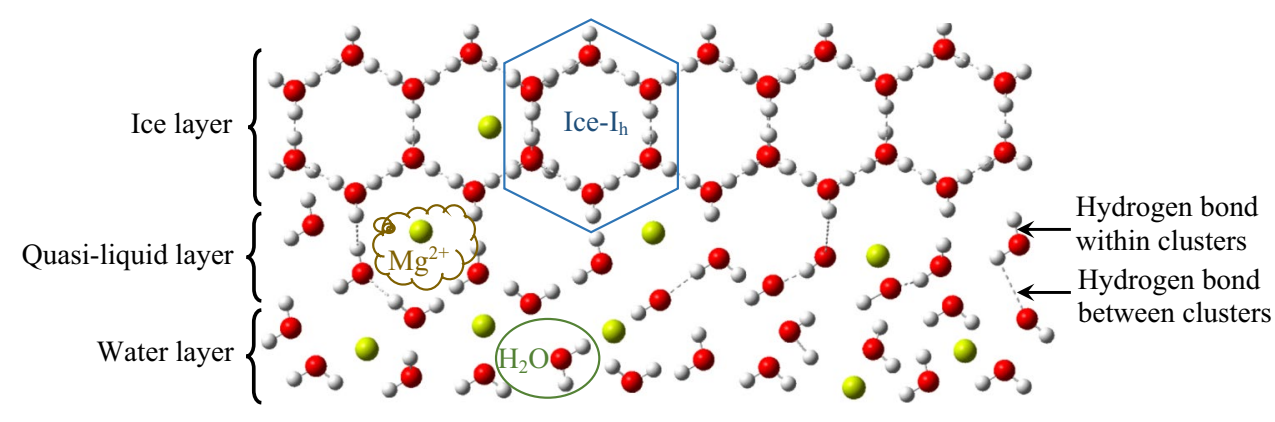


temperature, initial concentration, and initial $\mathrm{pH}$, the smaller the " $\mathrm{K}$ " value and the stronger the migration ability of $\mathrm{Mg}^{2+}$ to the water layer under ice.

The migration ability of $\mathrm{Mg}^{2+}$ in the ice and water twophase system is related to hydrogen bonding, which can be divided into hydrogen bonds formed between water clusters and hydrogen bonds formed within water clusters according to different hydrogen bond positions (Fig. 7). There is a competitive relationship between them, and the role of hydrogen bonds within clusters is far greater than that of hydrogen bonds between clusters (Wang and Wang 2001). Pure ice has a tetrahedral crystal structure and is formed by water molecules associating through hydrogen bonds (Sun 2019). The association among molecules will result in the release of a large amount of energy, and the rate of energy release determines the growth rate of ice crystals. When the energy is low, the thermal motion of water molecules is relatively weak, and the formation rate of hydrogen bonds is accelerated; thus, the formation rate of ice crystals is accelerated. Since the temperature is greater than the solution of the substance diffusion, the solid-liquid interface is dendritic growth (Shum and Papangelakis 2019), and $\mathrm{Mg}^{2+}$ have no time to "escape" and are trapped in the dendritic space to form ice cells (such as Fig. 8). Generally, higher growth rates lead to more complex ramifications in ice crystals and result in narrow channels with higher streaming resistance and less ions expulsion (Breitner 1953). The freezing temperature and ice thickness affect the energy release rate because the increase in ice sheet thickness hinders the heat exchange between the water layer under ice and the outside world. When the temperature is higher and the ice thickness is larger, the growth rate of ice crystals is lower; in the case of slow growth, the size of each ice crystal does not change much, and $\mathrm{Mg}^{2+}$ and water molecules form a relatively balanced relationship between the ice and water two-phase system. The volume of newly formed ice crystals increases, but the ability to capture $\mathrm{Mg}^{2+}$ decreases (Okawa et al. 2009). Therefore, with increased ice thickness and freezing temperature, the distribution coefficient " $\mathrm{K}$ " of $\mathrm{Mg}^{2+}$ in the ice and water two-phase system decreases.

In addition, hydrogen bonds between water clusters also affect the migration ability of $\mathrm{Mg}^{2+}$ in the ice and water

Fig. 8 Ice cell structure. Freezing temperature of $-15^{\circ} \mathrm{C}$, $40 \times$ magnification two-phase system. For the hydrogen bonds formed between water clusters, when the solution concentration increases, the effect of hydrogen bonds between clusters increases (Wang et al. 2010), the diffusion coefficient decreases, more granular ice crystals are formed, and the surface area of ice crystals increases (Yu et al. 2007). Although more $\mathrm{Mg}^{2+}$ have no time to "escape" and be captured in the ice layer at the early stage of icing, with the increase in ice thickness, the crystal grows at a uniform speed and $\mathrm{Mg}^{2+}$ continue to migrate, and the increase of $\mathrm{Mg}^{2+}$ in the ice layer is much smaller than that in the water layer under ice, leading to a decreased "K" value. Similarly, the increase of $\mathrm{pH}$ can lead to a fundamental change in the structure of water clusters in $\mathrm{Mg}^{2+}$ solutions. With increased $\mathrm{pH}$, the distance between $\mathrm{Mg}-\mathrm{O}$ atoms decreases ( $\mathrm{Li}$ et al. 2004), which makes the hydration number of $\mathrm{Mg}^{2+}$ in the electrolyte solution decrease (Kang et al. 2014); the "escape" rate of $\mathrm{Mg}^{2+}$ to the water is accelerated, which makes it difficult to capture with ice layer; and there are fewer $\mathrm{Mg}^{2+}$ left in the ice layer after freezing. Therefore, with the increase of initial concentration and initial $\mathrm{pH}$, the distribution coefficient " $\mathrm{K}$ " of $\mathrm{Mg}^{2+}$ in the ice and water two-phase system decreases.

\section{Effects of different factors on $\mathrm{Mg}^{2+}$ release during ice melting}

The results of ice melting experiments showed that the release law of $\mathrm{Mg}^{2+}$ from the ice phase was consistent with different conditions during the melting process: In the early stage of melting (0-25\%), a large amount of $\mathrm{Mg}^{2+}$ were rapidly released in a short time. The concentration of $\mathrm{Mg}^{2+}$ in the initial melting stage was much higher than the average concentration of $\mathrm{Mg}^{2+}$ in the ice layer, and then the release rate of $\mathrm{Mg}^{2+}$ rapidly decreased, showing a small amount of uniform release phenomenon. The concentration of $\mathrm{Mg}^{2+}$ in the middle and late stages was significantly lower than the average concentration of $\mathrm{Mg}^{2+}$ in the ice layer.

In the ice melting process, the surface ice begins to melt, and droplets form on the ice surface (such as Fig. 9). The melting rate depends on the heat transfer from the environment to the melting interface, and the melting rate of ice is equivalent to the growing rate of droplets on the melting interface (Nakagawa et al. 2010). The growth of droplets is a continuous process, and $\mathrm{Mg}^{2+}$ can be attached to the growing droplets, which is defined as "solute elution" (Shafique et al. 2012). "Solute elution" into droplets will be limited by the droplet growth rate. Therefore, the dynamic equilibrium between the droplet growth rate and $\mathrm{Mg}^{2+}$ diffusion rate determines the concentration of $\mathrm{Mg}^{2+}$ in the melting process. When the diffusion coefficient of $\mathrm{Mg}^{2+}$ is sufficiently large in the refrigerant liquid phase, the growth rate of droplets will affect the concentration level in the melting stage. In other words, slow droplet growth conditions are conducive 


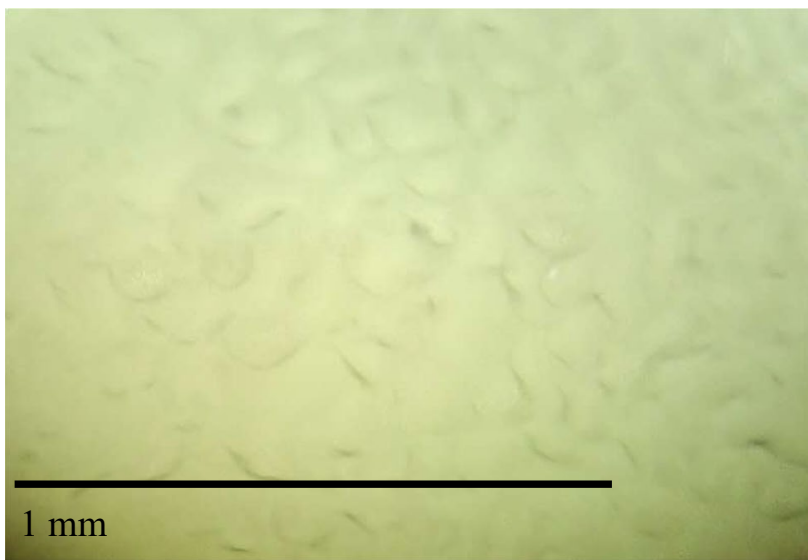

Fig. 9 The surface of the solid continues to melt, $200 \times$ magnification

Fig. 10 Ice channel structure. Freezing temperature of $-15^{\circ} \mathrm{C}$, $40 \times$ magnification

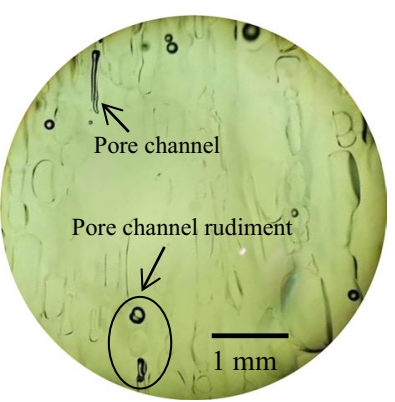

to the recovery of solutes with high yields (Badawy 2016). In the early melting period, with the increase and interconnection of melting pores, many pore channels connecting the ice interior are formed (such as Fig. 10), and the ice layer becomes loose and disintegrates, resulting in the release of a large amount of $\mathrm{Mg}^{2+}$ in the early stage of ice melting. With ice layer melting, most $\mathrm{Mg}^{2+}$ have "escaped" out of the ice layer along the channel, leaving only a small amount of $\mathrm{Mg}^{2+}$ in ice layer. In the middle and later periods of melting, the release of $\mathrm{Mg}^{2+}$ shows a decreasing trend, and the number of $\mathrm{Mg}^{2+}$ is small and uniform.

\section{Exponential model of ice melting}

To quantitatively describe the release law of $\mathrm{Mg}^{2+}$ in melting, the origin is used to fit the data of melting water under various conditions. The results show that as the cumulative volume ratio of ice melt water increases, the ratio of $\mathrm{Mg}^{2+}$ concentration in ice melt water to the concentration of ice layer decreases, and the relationship between them decreases exponentially, as shown in Fig. 11. The fitting parameters are shown in Tables 5-8. The general formula is

$Y=A \times e^{\frac{-x}{t}}+y_{0}$

where $A, t$, and $y_{0}$ are correction coefficients affected by many factors, such as ice thickness, freezing temperature, initial concentration, and initial pH. $X$ is the cumulative volume ratio of ice melt water, and $Y$ is the concentration of $\mathrm{Mg}^{2+}$ in ice melt water $\left(\mathrm{mg} \cdot \mathrm{L}^{-1}\right)$.
Fig. 11 The fitting curves of the change in $\mathrm{Mg}^{2+}$ concentration under different freezing conditions

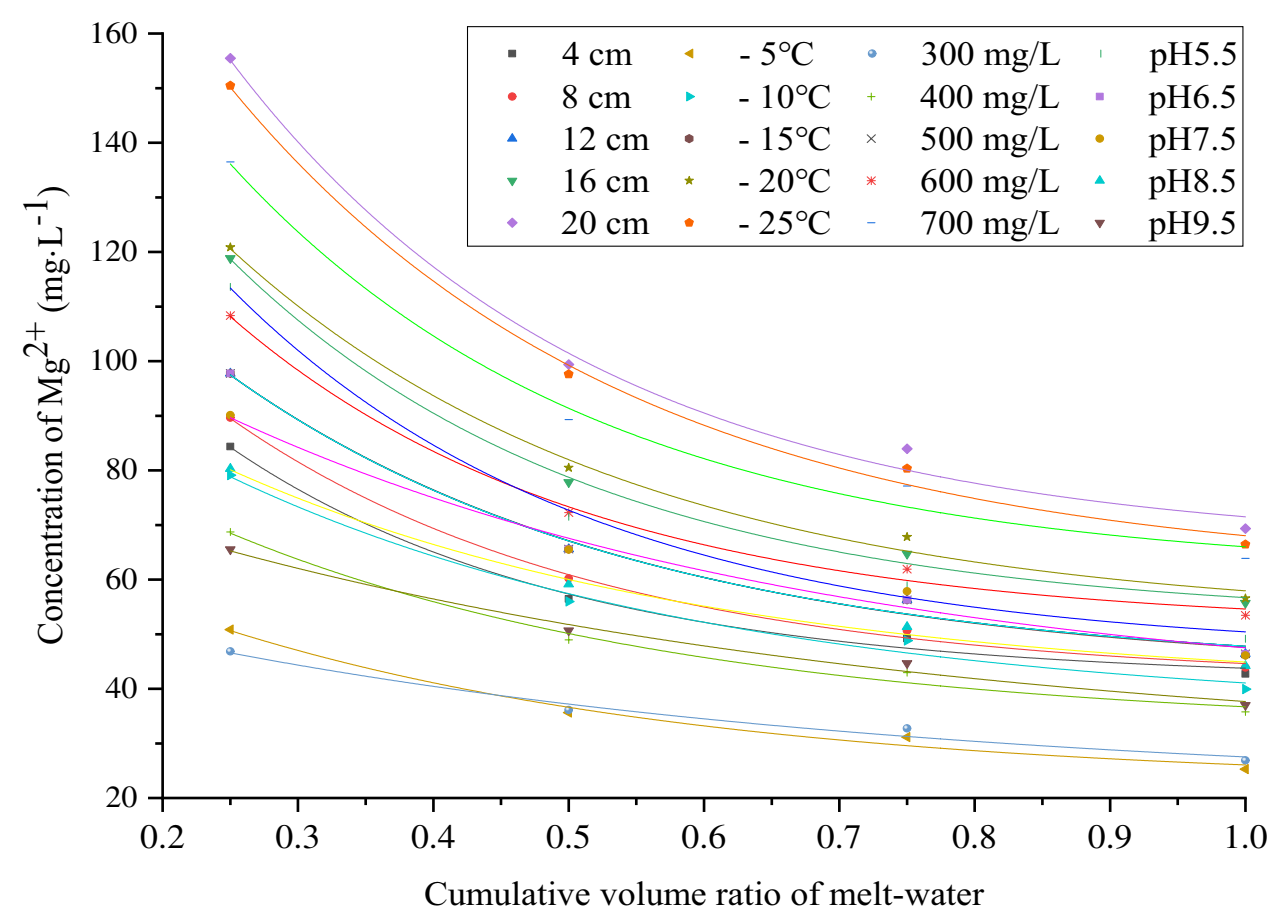


Table 5 Parameter values under different ice thicknesses

\begin{tabular}{llllll}
\hline Drawing & $4 \mathrm{~cm}$ & $8 \mathrm{~cm}$ & $12 \mathrm{~cm}$ & $16 \mathrm{~cm}$ & $20 \mathrm{~cm}$ \\
\hline$y_{0}$ & $41.62 \pm 3.43$ & $41.42 \pm 2.86$ & $43.15 \pm 6.48$ & $52.61 \pm 3.69$ & $65.83 \pm 8.32$ \\
$A$ & $115.43 \pm 23.31$ & $118.76 \pm 14.15$ & $123.36 \pm 23.30$ & $167.20 \pm 19.92$ & $223.85 \pm 43.49$ \\
$t$ & $0.25 \pm 0.06$ & $0.28 \pm 0.05$ & $0.30 \pm 0.10$ & $0.27 \pm 0.04$ & $0.27 \pm 0.07$ \\
$\begin{array}{r}R^{2} \text { (coefficient of } \\
\text { determination) }\end{array}$ & 0.99 & 1.00 & 0.99 & 1.00 & 0.99 \\
Adjusted $R^{2}$ & 0.98 & 0.99 & 0.98 & 0.99 & 0.98 \\
\hline
\end{tabular}

Table 6 Parameter values under different freezing temperatures

\begin{tabular}{llllll}
\hline Drawing & $-5^{\circ} \mathrm{C}$ & $-10^{\circ} \mathrm{C}$ & $-15^{\circ} \mathrm{C}$ & $-20^{\circ} \mathrm{C}$ & $-25^{\circ} \mathrm{C}$ \\
\hline$y_{0}$ & $22.52 \pm 5.14$ & $35.41 \pm 7.70$ & $42.72 \pm 6.83$ & $52.38 \pm 6.33$ & $60.99 \pm 7.04$ \\
$A$ & $56.16 \pm 10.28$ & $85.67 \pm 14.51$ & $122.76 \pm 23.33$ & $157.31 \pm 24.20$ & $207.82 \pm 28.08$ \\
$t$ & $0.36 \pm 0.16$ & $0.37 \pm 0.15$ & $0.31 \pm 0.10$ & $0.30 \pm 0.07$ & $0.30 \pm 0.06$ \\
$R^{2}$ (coefficient of & 0.99 & 0.99 & 0.99 & 1.00 & 1.00 \\
$\quad$ determination) & & & & & 0.99 \\
Adjusted $R^{2}$ & 0.97 & 0.97 & 0.98 & 0.99 & 0.99 \\
\hline
\end{tabular}

Table 7 Parameter values under different initial concentrations

\begin{tabular}{llllll}
\hline Drawing & $300 \mathrm{mg} \cdot \mathrm{L}^{-1}$ & $400 \mathrm{mg} \cdot \mathrm{L}^{-1}$ & $500 \mathrm{mg} \cdot \mathrm{L}^{-1}$ & $600 \mathrm{mg} \cdot \mathrm{L}^{-1}$ & $700 \mathrm{mg} \cdot \mathrm{L}^{-1}$ \\
\hline$y_{0}$ & $21.07 \pm 10.12$ & $32.46 \pm 5.82$ & $43.15 \pm 6.48$ & $51.31 \pm 4.18$ & $61.05 \pm 8.31$ \\
$A$ & $40.34 \pm 5.53$ & $73.57 \pm 13.01$ & $123.35 \pm 23.30$ & $146.80 \pm 24.23$ & $185.88 \pm 41.55$ \\
$t$ & $0.55 \pm 0.40$ & $0.35 \pm 0.14$ & $0.30 \pm 0.10$ & $0.26 \pm 0.06$ & $0.28 \pm 0.09$ \\
$R^{2}$ (coefficient of & 0.98 & 0.99 & 0.99 & 1.00 & 0.99 \\
$\quad$ determination) & & 0.97 & 0.98 & 0.99 & 0.98 \\
Adjusted $R^{2}$ & 0.95 & & & & \\
\hline
\end{tabular}

Table 8 Parameter values under different initial $\mathrm{pH}$ values

\begin{tabular}{llllll}
\hline Drawing & $\mathrm{pH} \mathrm{5.5}$ & $\mathrm{pH} \mathrm{6.5}$ & $\mathrm{pH} \mathrm{7.5}$ & $\mathrm{pH} \mathrm{8.5}$ & $\mathrm{pH} \mathrm{9.5}$ \\
\hline$y_{0}$ & $46.35 \pm 4.65$ & $43.15 \pm 6.48$ & $37.51 \pm 14.77$ & $39.84 \pm 4.60$ & $27.95 \pm 10.90$ \\
$A$ & $170.63 \pm 25.62$ & $123.35 \pm 23.30$ & $90.48 \pm 12.97$ & $80.41 \pm 9.22$ & $58.405 \pm 5.85$ \\
$t$ & $0.27 \pm 0.05$ & $0.30 \pm 0.10$ & $0.45 \pm 0.26$ & $0.36 \pm 0.10$ & $0.56 \pm 0.30$ \\
$R^{2}$ (coefficient of & 1.00 & 0.99 & 0.98 & 1.00 & 0.99 \\
$\quad$ determination) & & 0.98 & 0.96 & 0.99 & 0.97 \\
Adjusted $R^{2}$ & 0.99 & & & & \\
\hline
\end{tabular}

By fitting the curve, the parameter values under various conditions can be obtained, as shown in Tables 5, 6, 7 and 8 . According to the experimental conditions, the values of $A$, $t$, and $y_{0}$ are appropriately selected and substituted into the above equation to calculate the $\mathrm{Mg}^{2+}$ concentration of ice melt water in the melting process under specific conditions.

\section{Conclusion}

(1) In the process of water freezing, $\mathrm{Mg}^{2+}$ is discharged, which leads to $\mathrm{Mg}^{2+}$ migrating from the ice layer into the water layer under ice, and the concentration of $\mathrm{Mg}^{2+}$ in the water layer under ice increases. The migration effect has a more significant impact on shallow lakes at high latitudes, so more attention should be paid to the detection of $\mathrm{Mg}^{2+}$ pollution in the water under ice in winter.

(2) In the water freezing process, distribution coefficient " $\mathrm{K}$ " decreases with increasing ice thickness, freezing temperature, initial concentration, and initial $\mathrm{pH}$; in other words, higher freezing temperature, ice thickness, initial concentration, and initial $\mathrm{pH}$ are conducive to the migration of $\mathrm{Mg}^{2+}$ to the water layer under ice. Other factors (such as light and radiation) may also influence $\mathrm{Mg}^{2+}$ migration during the freezing process, which must be further explored. 
(3) In the early period of ice melting (0-25\%), a large number of $\mathrm{Mg}^{2+}$ are rapidly released in a short time, and the release rate of $\mathrm{Mg}^{2+}$ decreases rapidly in the middle and later periods $(25-100 \%)$, showing a small and uniform release phenomenon. Therefore, in the early melting stage of lake ice, the preferential centralized release of pollutants may have a great impact on the ice water environment, which needs the attention of limnologists.

Author contribution Z Y and L TS are the experimental designers and executors of this study; Z Y, L TS, and T YQ completed data analysis; Z Y and L TS wrote the first draft of their papers; Z WL, R FY, and Z TG participated in the experimental design and analysis of the experimental results; Z Y and L YC are the designers and directors of the project, guiding the experimental design, data analysis, thesis writing, and revision. All authors read and agree to the final text.

Funding The authors would like to appreciate the financial support by the Key Research and Development Program of Shandong Province (2019GHY112033), the National Natural Science Foundation of China (No.51609207), and Graduate Innovation Foundation of Yantai University, GIFYTU (YDZD2101).

Data availability Not applicable.

\section{Declarations}

Ethics approval and consent to participate Not applicable.

Consent for publication Not applicable.

Competing interests The authors declare no competing interests.

Open Access This article is licensed under a Creative Commons Attribution 4.0 International License, which permits use, sharing, adaptation, distribution and reproduction in any medium or format, as long as you give appropriate credit to the original author(s) and the source, provide a link to the Creative Commons licence, and indicate if changes were made. The images or other third party material in this article are included in the article's Creative Commons licence, unless indicated otherwise in a credit line to the material. If material is not included in the article's Creative Commons licence and your intended use is not permitted by statutory regulation or exceeds the permitted use, you will need to obtain permission directly from the copyright holder. To view a copy of this licence, visit http://creativecommons.org/licenses/by/4.0/.

\section{References}

Badawy SM (2016) Laboratory freezing desalination of seawater. Desalin Water Treat 57(24):11040-11047

Breitner HJ (1953) Entmischung beim gefrieren wsseriger lsungen. Deutsche Hydrographische Zeitschrift 6(2):80-86. https://doi.org/ 10.1007/BF02019700
Catalan J (1992) Evolution of dissolved and particulate matter during the ice-covered period in a deep, high-mountain lake. Can J Fish Aquat Sci 49(5):945-955

Chen RY, Song XL, Zhang ST, Zhang ZX, Yang W (2008) Dianchi lake sediment records of climate changes and humane activities in the past 700 years. J Salt Lake Research 16(2):7-12 ((in Chinese))

Chiou CT, Malcolm RL, Brinton TI, Kile DE (1986) Water solubility enhancement of some organic pollutants and pesticides by dissolved humic and fulvic acids. Environ Sci Technol 20(5):502-508

Cui FL, Li CY, Shi XH, Shi YQ, Fu XJ (2013) Seasonal changing characteristics of the major ions in the lake wuliangsuhai. J Arid Land Resources and Environment 27(08):137-142 ((in Chinese))

Dai D (2016) Responses of lake water calcium and magnesium to regional acid deposition and algae blooms in Taihu Lake. Dissertation, Chinese Research Academy of Environmental Sciences (In Chinese)

Guan XY (2017) The correlation between serum magnesium and chronic kidney disease complications. Dissertation, Jilin University (in Chinese)

Hampton SE, Moore MV, Ozersky T, Stanley EH, Polashenski CM, Galloway A (2015) Heating up a cold subject: prospects for underice plankton research in lakes. J Plank Res 37(2):277-284

Huang J, Fu X, Wang X, Liu N, Liu D (2009) The distribution characteristics of nutrients and phytoplankton during the icebound season in Changchun. Acta Sci Circum 29(8):1678-1683 ((in Chinese)

Huang J, Li S, Yu W, Gao Q, Hao F (2012) Distribution characteristics of nutrients and chlorophyll-a in a lake during the icebound season: a case study of a landscape lake in changchun, china. APCBEE Proc 1:8-15

Jewson DH, Granin NG, Zhdanov AA, Gnatovsky RY (2009) Effect of snow depth on under-ice irradiance and growth of Aulacoseira baicalensis in lake Baikal. Aquat Ecol 43(3):673-679

Kang KC, Linga P, Park KN (2014) Seawater desalination by gas hydrate process and removal characteristics of dissolved ions $\left(\mathrm{Na}^{+}, \mathrm{K}^{+}, \mathrm{Mg}^{2+}, \mathrm{Ca}^{2+}, \mathrm{B}^{3+}, \mathrm{Cl}^{-}, \mathrm{SO}_{4}{ }^{2-}\right)$. Desalination 353:84-90

Kirillin G, Lepparanta M, Terzhevik A, Granin NG (2012) Physics of seasonally ice-covered lakes: a review. Aquat Sci 74(4):659-682

Li WP, Xu J, Yu LH, Li X, Han PJ, Zhan Z, Jing J (2014) Distribution characteristics of nutrients and phytoplankton in Wuliangsuhai Lake during the icebound season. Ecol Environ 23(6):1007-1013 ((in Chinese))

Li XL, Pan G, Zhu YQ (2004) EXAFS study influence of pH on microscopic structure of zinc. Nuclear Techniques 27(12):895-898 ((In Chinese)

Liu Y, Li CY, Anderson B, Zhang S, Shi XH, Zhao SNN (2017) A modified QWASI model for fate and transport modeling of mercury between the water-ice-sediment in Lake Ulansuhai. Chemosphere 176(JUN):117-124

Liu Y, Zhang S, Li CY, Shi XH, Zhao SNN, Sun B, Zhu YH (2019) A modified QWASI model for fate and transport modeling of $\mathrm{Zn}$ and $\mathrm{Pb}$ in a shallow lake during the ice-free period. Sci Total Environ 657(MAR.20):577-584

Melak F, Du LG, Ambelu A, Alemayehu E (2016) Application of freeze desalination for chromium (VI) removal from water. Desalination 377:23-27

Musso CG (2009) Magnesium metabolism in health and disease. Int Urol Nephrol 41(2):357

Nakagawa K, Maebashi S, Maeda K (2010) Freeze-thawing as a path to concentrate aqueous solution. Sep Pure Technol 73(3):403-408

Okawa S, Ito T, Saito A (2009) Effect of crystal orientation on freeze concentration of solutions. Int J Refrig 32(2):246-252 
Pieters R, Lawrence GA (2009) Effect of salt exclusion from lake ice on seasonal circulation. Limnol Oceanogr 54(2):401-412

Shafique U, Anwar J, Munawar MA, Zaman WU, Rehman R, Dar A, Jamil N (2016) Chemistry of ice: migration of ions and gases by directional freezing of water. Arab J Chem 9:S47-S53

Shafique U, Anwar J, Rehman R, Salman M, Dar A, Jamil N (2012) Forced migration of soluble and suspended materials by freezing front in aqueous systems.J Hydro-Environ Res 6(3):221-226

Shum E, Papangelakis V (2019) Water recovery from inorganic solutions via natural freezing and melting. J Water Process Eng 31:100787

Sun B, Li B, Fang CH, Du XH, Song PS (1995) Studies on the phase diagram and solution properties for the Quinary System, $\mathrm{Li}+, \mathrm{K}+$, $\mathrm{Mg} 2+/ \mathrm{Cl}-, \mathrm{SO} 42-\mathrm{H} 2 \mathrm{O}$ at $25^{\circ} \mathrm{C}$. J Salt Lake Science 04:50-56 ((in Chinese))

Sun C (2019) Transport characteristics of heavy metals based on first principle in ice-water in the lake Ulansuhai. Dissertation, Inner Mongolia Agricultural University (In Chinese)

Sun C, Li CY, Liu JJ, Shi XH, Zhao SN, Wu Y, Tian WD (2018) Firstprinciples study on the migration of heavy metal ions in ice-water medium from ulansuhai lake. Water 10(9)

The State Environmental Protection Administration the Water and Wastewater Monitoring Analysis Method Editorial Board (2002)
Water and wastewater monitoring analysis method, 4th edn. Beijing, China, China Environmental Science Press

Verpoorter C, Kutser T, Seekell DA, Tranvik LJ (2014) A global inventory of lakes based on high-resolution satellite imagery. Geophys Res Lett 41(18):6396-6402

Wang LS, Wang RS (2001) Progress in studies of water cluster. Progress in Chemistry 13(2):81-86 ((In Chinese))

Wang WH, Zhao L, Yan B (2010) Effects of ions on structure of liquid water. Chemistry Bulletin73 (6):491-498 (In Chinese)

Welch HE, Legault JA, Bergmann MA (1987) Effects of snow and ice on the annual cycles of heat and light in Saqvaqjuac Lakes. Can J Fish Aquat Sci 44(8):1451-1461

WHO (2011) Guidelines for drinking-water quality, 4th edn. World Health Organization, Geneva

Wisniak, (2002) The dead sea-a live pool of chemicals. Indian J Chem Techn 9(1):79-87

Yu T, Ma JZ, Li Q (2007) Factors affecting ice crystal purity during freeze concentration process for urine treatment. J Harbin Institute of Technology 14(5):593-597 ((In Chinese))

Publisher's Note Springer Nature remains neutral with regard to jurisdictional claims in published maps and institutional affiliations. 